GRASAS Y ACEITES, 62 (1), ENERO-MARZO, 29-38, 2011, ISSN: 0017-3495

DoI: $10.3989 /$ gya. 056210

\title{
Vegetable oils as hydraulic fluids for agricultural applications
}

\author{
By G. Mendoza, ${ }^{a}$ A. Igartua,,${ }^{a}{ }^{,}$B. Fernandez-Diaz, ${ }^{a}$ F. Urquiola, ${ }^{b}$ S. Vivanco ${ }^{b}$ and R. Arguizoniz ${ }^{c}$ \\ a Fundación TEKNIKER, Av. Otaola, № 20, 20600-Eibar, Gipúzcoa (Spain) \\ ${ }^{b}$ Verkol Lubricantes, Barrio de Zalain, ํㅡㄴ, 31789-Bera, Navarra (Spain) \\ ${ }^{c}$ Agria Hispania S.A. , Barrio Euba, s/n ,48340-Amorebieta, Vizcaya (Spain) \\ ( ${ }^{\star}$ Corresponding autor: aigartua @ tekniker.es)
}

\begin{abstract}
RESUMEN
Aceites vegetales como fluidos hidráulicos en maquinaria agrícola

La formulación de lubricantes amigables con el medioambiente siguiendo los criterios Europeos de la EcoLabel resulta cara debido a la falta de desarrollo tecnológico en esta área. En el presente trabajo se han desarrollado formulaciones de lubricantes a partir de aceites de origen vegetal, en particular empleando como aceite base el GAO (Girasol de Alto Oleico). Estos nuevos lubricantes deben presentar un comportamiento tan bueno como el de los lubricantes de referencia empleados en la aplicación real (un tractor agrícola), pero con la condición y valor añadido de ser biodegradables y no tóxicos. Las formulaciones han sido desarrolladas por Verkol lubricantes, comenzando por la selección del aceite base hasta el diseño del paquete de aditivos. La investigación llevada a cabo por Tekniker en el laboratorio ha cubierto diferentes aspectos. Se han caracterizado las propiedades físico-químicas más importantes, incluyendo su comportamiento a bajas temperaturas y su resistencia a la oxidación. También se han estudiado las propiedades tribológicas de los nuevos biolubricantes, analizando su habilidad para proteger frente al desgaste las superficies interactuantes, así como el nivel de fricción generado durante el deslizamiento. Paralelamente, se ha considerado la compatibilidad de las nuevas formulaciones de aceite con todas las juntas presentes en la aplicación real. El lubricante seleccionado está siendo ensayado en un tractor agrícola de AGRIA.
\end{abstract}

PALABRAS-CLAVE: Aceite de Girasol Alto Oleico - Desgaste - Fluidos hidráulicos - Fricción - Lubricantes biodegradables - Tribología.

\section{SUMMARY}

Vegetable oils as hydraulic fluids for agricultural applications

The formulation of environmentally friendly lubricants following the criterion of the European EcoLabel is expensive owing to the lack of technological development in this area. The present work deals with the development of lubricant formulations from vegetable oils, in particular using high oleic sunflower oil as base fluid. These new biolubricants have to perform as good as the reference lubricants used in the real application (an agricultural tractor) but with the additional condition and value of their biodegradability without toxicity. Formulation development has been performed by Verkol Lubricantes, involving the selection of the base oil and the design of the additive package. The investigation performed by Tekniker in the laboratory has covered different aspects, characterizing the most important physicochemical properties of the lubricants, including their behavior at low temperatures and their resistance to oxidation. The tribological properties of the new biolubricants have also been studied, analyzing their ability to protect the interacting surface from wear, as well as the level of friction generated during sliding. Moreover, the compatibility of the new formulated oil with all the seals present in the real application has been taken into consideration. The selected lubricant is now being tested in agricultural machinery from AGRIA.

KEY-WORDS: Biodegradable Lubricants - High Oleic Sunflower Oil - Hydraulic fluids - Friction - Tribology - Wear.

\section{INTRODUCCIÓN}

Lubricants are used extensively in machines and materials from all sectors of industry. Approximately $85 \%$ of all lubricants presently being used in the world are petroleum based oils (Shashidhara and Jayaram 2010). However, a slow but steady move towards the use of environmentally friendly or more readily biodegradable lubricant fluids has taken place during the last decade. Biodegradability has become one of the most important design parameters both in the selection of base fluids and in the overall formulation of the finished lubricant.

The demand for biodegradable lubricants is fed by a growing concern for the impact that industrial development has on our environment. This concern provoked a response in governments in the form of both local and national regulations (Rudnick, 2006). Biolubricants have been included in the list of products and services that can obtain the European Ecolabel since 13th May, 2005. This Ecolabel is given to those products that show a reduced impact on the environment and inform the end users about what they are buying (Igartua et al, 2005).

\subsection{Market of biodegradable lubricants}

Europe has been leading the biobased lubricant market for 20 years. In this regard, experts estimated that $18 \%$ of all lubricants used in Europe will be biobased in the next few years (Society of Tribologists, 2010). The market for biobased lubricants is driven by a combination of economic factors that include the high price of mineral oil, tax incentives to promote 
biobased products, the cost of recycling and penalties applied in the case of accidental release. There are also performance requirements and environmental regulations requiring biodegradability and low-toxicity in sensitive areas.

Biobased lubricant markets have the highest potential in the following cases:

- The application is total loss.

- The application is indoors where low pour point is not an issue.

- The application is in an environmentallysensitive area where leakage and spill risk make biodegradability extremely important.

- The purchase is required (i.e., because of federal regulations) (Van Rensselar, 2010).

Thus, biobased products in Europe are nowadays being successfully applied in metalworking and as industrial lubricants, greases, tractor oils and hydraulic fluids. The use of biobased automotive lubricants has been proven to be limited because of performance issues. However, some biobased products proved to be highly efficient as lubricity additives in formulations of Fuel-economy engine oils and transmission Fluids (Society of Tribologists, 2010).

From a global perspective, total lubricant demand is expected to be about 41.8 million metric tons, or about 13 billion gallons. Growth is expected to be about $2 \%$ over the next few years. The fastest growth will be in the Asia/Pacific region, with China being the major gainer.

In the world market, the segmentation by application area is:

- Engine oils - 48\%

- Process oils - 15.3\%

- Hydraulic oils - 10.2\%

- All other - $26.5 \%$

Moreover, the geographical segmentation is:

- Asia/Pacific - 36.7\%

- North America - 28\%

- Western Europe - 12.5\%

- Rest of world $-22.8 \%$

The total market for all lubricants in Western Europe is about 1.6 billion gallons, according to several published estimations (Bremmer and Plonsker, 2008). It is remarkable that according to the study by Frost and Sullivan (2007) on the European Bio-lubricants Market, the estimated use of bio-lubricants in 2006 was 127,000 tons, with growth rates of $3.7 \% / y r$ between 2000 and 2006 . This volume of growth is still modest, although revenue growth is larger because of the higher price of the bio-lubes (Frost and Sullivan, 2007).

The major vegetable oil in use in Europe for industrial products is rapeseed. However, not all bio-lubricants are completely vegetable oil-based. In some countries, getting a label of biolub only requires $50 \%$ of the oil to be renewable. Thus, synthetic esters or even petroleum oils can be used in the formulation (Bremmer and Plonsker, 2008).

\subsection{Hydraulic fluids}

Hydraulic fluids transmit power to the moving parts of many machines, including cars, bulldozers, tractors, and most heavy equipment used to build roads and structures. A good hydraulic fluid should have the following characteristics: power transmission with minimum loss, lubrication of surfaces moving against each other and corrosion protection of metal surfaces. They are an important group of industrial oils with a market share of $15 \%$ in Europe and $22 \%$ in The United States. The trend towards the rapidly growing use of bio-based oils is most noticeable in this area because of their biodegradability, recyclability, reasonable level of fire-resistance, good thermal stability and good wear performance in a broad range of temperatures. Vegetable oils have most of the required properties as potential candidates for hydraulic applications except that they have poor low temperature flow behavior and poor oxidation and hydrolytic stability. However, this can be overcome with the use of additives and by modifying the fatty acid composition of the basestock (Rudnick, 2006). Structural limitations of naturally occurring basestocks restrict the application of vegetable oil hydraulic fluids to moderate temperatures. Vegetable oils used in hydraulic fluids are triglycerides of fatty acids, mostly C18 unsaturated, and their oxidation stability depends on the degree of unsaturation of their fatty acids. Modifications of the acyl chain through plant hybridization, genetic alteration, and oil chemical and physical processing are aimed at shifting from unwanted polyunsaturated fatty acids to a higher content of oleic acid, and thus, to some extent, at improving the oxidation stability of vegetable oils. It is important to note that any modification of vegetable oils is accompanied by economic implications. In addition, the use of genetically modified oils as lubricant base stocks might meet the same public resistance that has been found for food facilities.

Another limitation, associated with the weakness of the beta carbon hydrogen in the polyol part, makes triglycerides more susceptible to thermal decomposition than common synthetic esters based on trimethylol propane, neopentyl glycol, and pentaerythritol.

Widening the range of temperature at which vegetable oils can be used is not a trivial problem. Nevertheless, by using oils with higher oleic acid content and, even more important, applying the appropriate additives, it is possible to significantly extend the useful life of vegetable oil hydraulic fluids at adequate working temperature ranges (Petlyuk and Adams, 2010). In this regard, biolubricants based on high oleic oils solved the problem of common vegetable oils lacking oxidative stability, although many of these formulations required mixing with other (often synthetic) oils to make their pour points lower. Still, achieving the cold temperature performance for lubricants used outdoors required the mixing in of various esters, which sometimes negatively affect the elastomeric compatibility of the final product (Honary, 2009). 


\section{DEVELOPED LUBRICANTS AND TESTING PROCEDURE}

A biolubricant should meet a series of imposed environmental requirements in addition to its technical performance. At present, there is a European reference, the Ecolabel, which was published in April 2005 with the aim of harmonizing and substituting the existing European standards (Blue Angel, Nordic Swan, NF-Environnment Mark...etc) for the lubricants which are compatible with the environment, mainly in Central and Northern Europe. This European standard establishes technical and ecological criteria that have to be evaluated and verified prior to obtaining the European Ecolabel for the lubricant.

The criteria to be applied can be summarized as:

- Criterion 1- Absence of R-phases indicating environmental and human hazards

- Criterion 2- Additional aquatic toxicity requirements

- Criterion 3- Biodegradability and bioaccumulative potencial

- Criterion 4- Exclusion of specific substances

- Criterion 5- Minimal content of renewable raw material

- Criterion 6- Technical performance

The first four criteria establish the limits for the composition of biolubricants either by direct exclusion of some substances (point 4) or by the limitation in the content of other substances that cannot pass the limits established in criteria 1,2 and 3 . It is important to indicate that point 2 and 3 establish the criteria that each lubricant substance (component) has to be analyzed separately in a way that the Ecolabel establishes a maximum content for them according to their toxicity, biodegradability and bio-accumulative potential. These points limit the use of some base oils but, above all, they limit the use of additives, making it difficult to fulfill some technical requirements when using rust and oxidation inhibitors, pour point depressants (PPD) and anti-wear and extreme pressure additives.

Point 5 establishes a minimal content of renewable raw materials, limiting the amount of synthetic bases to apply, forcing the use of bases mainly of vegetal or animal origin.

Point 6 establishes the technical requirements of biolubricants. For hydraulic fluids these requirements are defined in the ISO 15380 standard.

In this study several physicochemical and tribological tests have been performed at laboratory scale in order to check if the developed fluids fulfill the technical specifications required by the selected hydraulic system. These fluids consist of high oleic high sunflower oils containing as much as $83 \%$ oleic acid added to increase stability and depress the pour point. Biodegradability and toxicity tests have been carried out to ensure that new fluids meet the environmental requirements of the Ecolabel. Finally, the selected formulation has been tested in a real application: the hydraulic system of an agricultural tractor.

\subsection{Physicochemical aspects}

In order to check the properties of the developed bio-hydraulic fluids in comparison with the reference mineral fluid several tests have been performed with the aim of evaluating the most important physicochemical parameters required for common hydraulic fluids.

Hydraulic systems will work efficiently if the hydraulic oil used has low compressibility. Moreover, viscositiy at operating temperature and at coldstart temperature are also important properties. The viscosity at $40^{\circ} \mathrm{C}$ and $100^{\circ} \mathrm{C}$ have been measured according to ASTM D-445 and the Viscosity Index (VI) was calculated. At the same time, this type of oils must have a low pour point and a reasonable level of acidic content; these parameters have been measured following the ASTM-D97 (pour point) and ASTM 2274 (Acid number (AN)) standards respectively.

Another important parameter is oxidative stability; this property has been measured by means of the DSC test (Differential Scanning Calorimetry). The stability has been analyzed using an isothermal method under 20 bars of oxygen pressure maintaining the temperature at $145^{\circ} \mathrm{C}$ for 120 minutes. The Onset parameter is the time at which oil oxidation starts.

\subsection{Environmental aspects: biodegradability and toxicity}

There are different methods to determine the biodegradability and toxicity of the lubricants and their components. The evaluation has been done following the methods included in the European Eco-label for lubricants.

The tests to be applied for the determination of biodegradability and toxicity are:

- Ready biodegradability: OECD (Organization for cooperation and development, guidelines for testing of chemicals) $301 \mathrm{~A}-\mathrm{F}$ series, or ISO and ASTM equivalents or the BOD5/(THOD or COD) ratio for each constituent substance in the product separately.

- Aquatic toxicity: OECD 201, 202 and 203 or equivalent methods for the preparation or OECD 201 and 202 or equivalent methods for each individual main component.

\section{Biodegradability}

According to the European Eco-label for hydraulic fluids, a given substance is considered ultimately biodegradable when it gets $60 \%$ degradation in the OECD $301 \mathrm{~F}$ manometric respirometry test. One or more substances that are non-biodegradable and non-bio-accumulative are allowed in the end product for a maximum total mass content $\leq 5 \%$. A substance is considered inherently biodegradable if it shows a biodegradation higher than $70 \%$ in the OECD 302 C or equivalent test, or $>20 \%$ but $<60 \%$ in the OECD 301 test based on oxygen depletion or $\mathrm{CO}_{2}$ generation. 
In the OECD, 301F manometric respirometry test, a measured volume of inoculated mineral medium, containing a known concentration of test substance as the nominal sole source of organic carbon, is stirred in a closed flask at a constant temperature for 28 days. The consumption of oxygen is determined either by measuring the amount of oxygen required to maintain constant gas volume in the respirometer flask, or from the change in volume or pressure (or a combination of the two) in the apparatus. Evolved carbon dioxide is absorbed in a solution of potassium hydroxide. The amount of oxygen taken up by the microbial population during the biodegradation of the test substance, corrected for uptake by a blank inoculum run in parallel, is expressed as percentage of COD (Chemical Oxygen Demand).

\section{Toxicity}

The aquatic toxicity of each ingredient should be determined according to the OECD 201, 202 or equivalent methods. In the case of slightly soluble components the method of the water accommodated fraction (WAF) can be used in the aquatic toxicity determination. In these methods the effect load 50 $\left(E L_{50}\right)$ is measured. $E L_{50}$ is a statistically or graphically estimated loading rate of the test material which is expected to cause one or more specified effects in $50 \%$ of a representative subpopulation of organisms under specified conditions. This terminology should be used instead of the standard EC50 (Effective concentration 50) when the tested material is not completely water-soluble.

The requirements for hydraulic fluids according to the European Eco-label are described next. One or more chemical substances with EC50 $\leq 1.0$ $\mathrm{mg} / \mathrm{l}$ are allowed in the end product for a maximum mass content of $\leq 1 \%$. One or more substances with EC50>1.0 mg/l to $\leq 10 \mathrm{mg} / \mathrm{l}$ are allowed in the end product for a maximum mass content of $\leq 5 \%$. And, one or more substances with EC50>10 mg/l to $\leq 100 \mathrm{mg} / \mathrm{l}$ are allowed in the end product for a maximum mass content of $\leq 20 \%$.

In the OECD 201 test (alga growth inhibition test) exponentially-growing cultures of selected green algae are exposed to various concentrations of the test substance over several generations under defined conditions.

A 72-hour algal growth inhibition test is performed in long cell test vials, with Selenastrum capricornutum released from algal beads. Optical density (OD) at $670 \mathrm{~nm}$ is used as the parameter for algal growth / inhibition. The tests are performed in disposable cells of $10 \mathrm{~mm}$ path-length which allow direct and rapid scoring of the $\mathrm{OD}$, using any conventional colorimeter equipped with a holder for $1 \mathrm{~cm}$ cells.

EC50 is the concentration of the test substance which results in a 50 per cent reduction in either growth or growth rate relative to the control.

In the OECD 202 test Daphnia magna or the 24h EC50 Acute Immobilization test, a range of concentrations of the substance investigated exerts different degrees of toxic effects on the swimming capability of Daphnia under otherwise identical testing conditions. Certain concentrations result in certain percentages of Daphnia being no longer capable of swimming after 24 hours. The Daphnia magna must be no more than 24 hours old at the beginning of the test, laboratory bred and apparently healthy. The percentage of immobility after 24 hours is determined for each dilution. Normal statistical procedures are then used to calculate the EC50 for the appropriate exposure period.

The measurement of the inhibitive effect on Daphnia of the test sample is the EC50 value, determined graphically or by calculation. This indicates the concentration of the test sample at which $50 \%$ of the Daphnia used become incapable of swimming within the test period of 24-hours.

\subsection{Tribological tests}

\section{Four ball tests (extreme pressure test)}

Basic tribological tests are normally far away from the working conditions of the critical elements, but normally give an idea of the general wear and friction properties of materials and lubricants. By means of the Four Ball Machine it is possible to study the extreme pressure characteristics of lubricants. The four ball tests have been made according to standard ASTM D 2783. These tests are thought to evaluate the behavior of the lubricants under high unitary loads. A scheme of the testing configuration and the testing conditions are shown in Figure 1 and Table 2 respectively. In this test the welding load is obtained. The welding load is the load at which the balls connect to each other by effect of temperature and pressure. Figure 2 shows the welded balls during the test. Reciprocating ball on disc Tests (Abrasion tests)

The "ball on disc" tests have been made to study the friction and wear properties of the reference mineral oils and new bio lubricant oils under reciprocating movement in a point to area system. By means of this test it is possible to select different lubricants in relation to their ability to avoid wear mechanisms and maintain stable friction. A scheme of the testing configuration and the testing conditions are shown in Figure 1 and Table 2 respectively.

\subsection{Seals compatibility (ASTM D471)}

Some polymeric components such as seals are exposed to lubricants, greases or other fluids during their service lives in a continuous or intermittent way. During exposure to these fluids the properties of the polymeric materials can deteriorate, mainly affecting their dimensional characteristics, physicochemical and mechanical properties.

In order to evaluate the effects of the developed hydraulic fluids on the elastomeric seals, the screening test ASTM D471 has been used. It is a standardized immersion test, using the elastomer immersed in the 


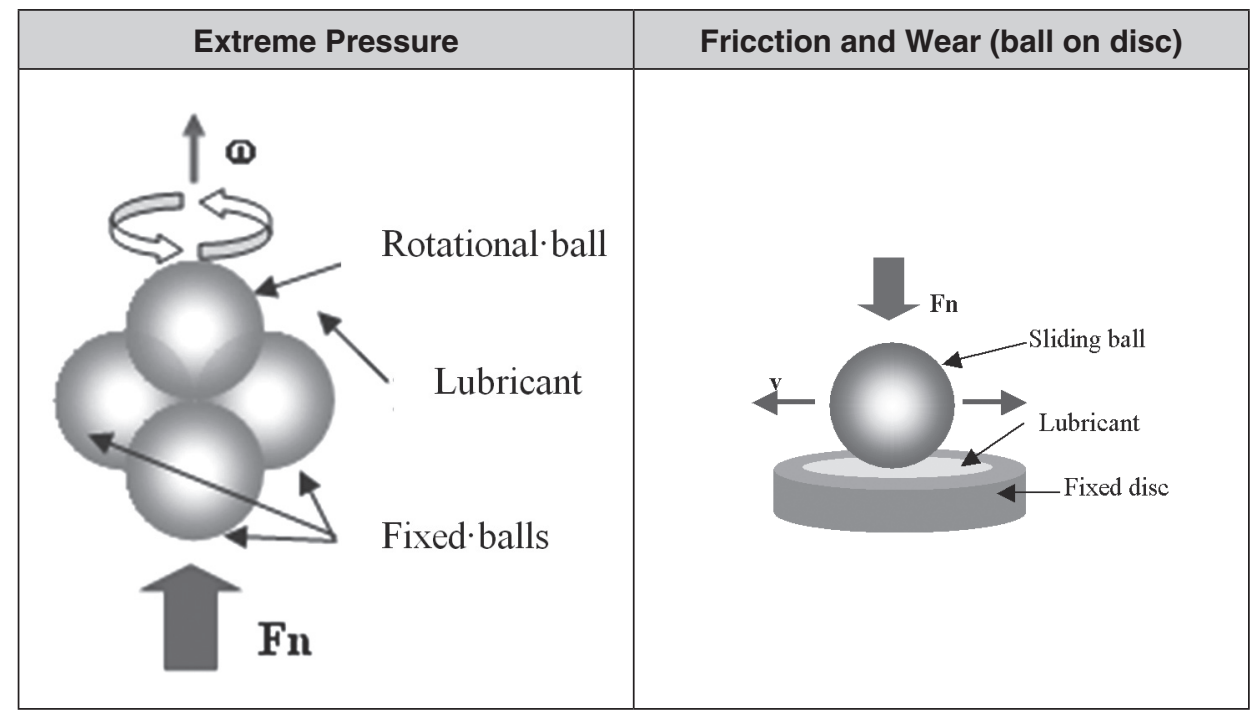

Figure 1. Tribological tests configurations

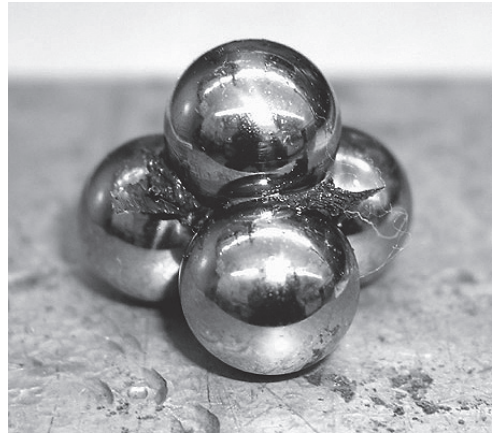

Figure 2. Balls welded during the four ball extreme pressure test

actual fluid, at appropriate temperatures, under static conditions.

The determination of the resulting deterioration is evaluated measuring the changes in physical properties (Shore A hardness), changes in appearance, dimension, mass and density, before and after immersion in the test fluid.

The immersion period and temperature depend on the service conditions; in this case $80^{\circ} \mathrm{C}$ and $168 \mathrm{~h}$ have been selected.

The experimental tests have been carried out with the real seals used in the hydraulic system of the AGRIA's agricultural tractor (see Figure 6) against the reference hydraulic oil and the new developments.

\section{EXPERIMENTAL RESULTS}

\subsection{Physicochemical properties}

Table 3 shows the results obtained in the different physicochemical test performed in order to characterize the most relevant properties of the fluids

Table 1

Tested fluids

\begin{tabular}{|c|c|c|c|}
\hline Code & Base & Additives & \\
\hline RAGH & Mineral & Standard additives package & Reference Lubricant \\
\hline HOSO & Vegetal & None & No added oils \\
\hline BIOGIR-01 & Vegetal $\mathrm{HOSO}^{\mathrm{a}}$ & Additives package 1 & \multirow{6}{*}{$\begin{array}{l}\text { Developed Lubricants } \\
\text { (Added oils) }\end{array}$} \\
\hline BIOGIR-02 & Vegetal $\mathrm{HOSO}^{\mathrm{a}}$ & $R O^{b}-1+A W^{c}-1$ & \\
\hline BIOGIR-03 & Vegetal HOSO ${ }^{\mathrm{a}}$ & $R O^{b}-2+A W^{c}-1$ & \\
\hline BIOGIR-04 & Vegetal HOSO ${ }^{a}$ & ESTER-1 + RO ${ }^{\mathrm{b}}-2+\mathrm{AW}^{\mathrm{c}}-2+\mathrm{PPD}^{\mathrm{d}}$ & \\
\hline BIOGIR-05 & Vegetal HOSO ${ }^{a}$ & ESTER-1 + RO ${ }^{\mathrm{b}}-2+\mathrm{AW}^{\mathrm{c}}-3+\mathrm{PPD}^{\mathrm{d}}$ & \\
\hline BIOGIR-06 & Vegetal HOSO ${ }^{\mathrm{a}}$ & ESTER-2 + RO ${ }^{\mathrm{b}}-2+\mathrm{AW}^{\mathrm{c}}-2+\mathrm{PPD}^{\mathrm{d}}$ & \\
\hline
\end{tabular}

${ }^{a}$ HOSO: High Oleic Sunflower Oil, with $83 \%$ oleic acid. ${ }^{b}$ RO: Rust and Oxidation inhibitor. ${ }^{c}$ AW: Anti-Wear additive. ${ }^{d}$ PPD: Pour Point Depressant. 
Table 2

Tribological testing conditions

\begin{tabular}{|c|c|c|}
\hline Testing conditions & $\begin{array}{l}\text { Extreme pressure } \\
\text { (Four ball) }\end{array}$ & $\begin{array}{l}\text { Friction and Wear } \\
\text { (ball-on disc) }\end{array}$ \\
\hline Standard & ASTM 2783 & DIN 51834 \\
\hline Ball & $\varnothing 10 \mathrm{~mm}, 100 \mathrm{Cr} 6$ & $\varnothing 10 \mathrm{~mm}, 100 \mathrm{Cr} 6$ \\
\hline Disc & - & $\varnothing 24 \mathrm{~mm}, 100 \mathrm{Cr} 6$ \\
\hline Applied Load ${ }^{\mathrm{a}}$ & $6,8, \ldots, 100, \ldots, 800 \mathrm{~kg}$ & $50 / 300 N$ \\
\hline Testing time & $10 \mathrm{~s}$ (each load) & $2 \mathrm{~h}$ \\
\hline Initial temperature & $18-35 \stackrel{\circ}{ } \mathrm{C}$ & $50^{\circ} \mathrm{C}$ \\
\hline Speed & $1760 \pm 40 \mathrm{rpm}$ & $0.1 \mathrm{~m} / \mathrm{s}^{\mathrm{b}}$ \\
\hline
\end{tabular}

Table 3

Physicochemical tests results

\begin{tabular}{|c|c|c|c|c|c|c|}
\hline Lubricant & $\begin{array}{c}\eta \text { at } 40^{\circ} \mathrm{C} \\
\text { (cSt) }\end{array}$ & $\begin{array}{c}\eta \text { at } 100^{\circ} \mathrm{C} \\
\text { (cSt) }\end{array}$ & $\begin{array}{l}\text { VI } \\
\text { ( ) }\end{array}$ & $\begin{array}{c}\text { AN } \\
(\mathrm{mgKOH} / \mathrm{g})\end{array}$ & $\begin{array}{l}\text { Pour point } \\
\quad\left({ }^{\circ} \mathrm{C}\right)\end{array}$ & $\begin{array}{c}\text { OIT } \\
\text { (min) }\end{array}$ \\
\hline RAGH & 48.7 & 8.3 & 145 & 0.54 & -34 & $>120$ \\
\hline HOSO & 39.3 & 8.5 & 202 & 0.06 & -3 & 8 \\
\hline BIOGIR-01 & 39.8 & 8.5 & 199 & 0.55 & -15 & 20 \\
\hline BIOGIR-02 & 40.2 & 8.5 & 197 & 0.37 & -18 & 37 \\
\hline BIOGIR-03 & 40.3 & 8.6 & 198 & 0.46 & -18 & 88 \\
\hline BIOGIR-04 & 36.1 & 8.0 & 204 & 0.71 & -27 & 60 \\
\hline BIOGIR-05 & 35.9 & 8.0 & 205 & 0.79 & -29 & 68 \\
\hline BIOGIR-06 & 42.1 & 8.8 & 196 & 0.78 & -27 & 71 \\
\hline
\end{tabular}

developed. The composition of the tested formulation is shown in Table 1. It is important to note the high viscosity index of the reference hydraulic fluids. This is an inherent property which is naturally present in the vegetable base oils.

Concerning the acid content, this value is acceptable in the new vegetable based formulations in comparison with the reference oil.

The pour point obtained for the new formulations varies between $-15^{\circ} \mathrm{C}$ and $-29^{\circ} \mathrm{C}$, considering that the pour point of $\mathrm{HOSO}$ oil is $-3^{\circ} \mathrm{C}$, it can be said that the low temperature resistance has been substantially improved with the additive, especially for BIOGIR-04, BIOGIR-05 and BIOGIR-06.

Another disadvantage of vegetable oils is their low oxidation resistance. Again, the additive has substantially improved the oxidation stability of the sunflower base oil.

\subsection{Biodegradability and toxicity}

In Table 4 it can be seen that all the biohydraulic fluids developed by far reach $60 \%$ bidegradability in the OECD 301F tests so according to Eco- label criteria they can be considered ultimately biodegradable. However the reference fluid cannot be considered biodegradable.

In terms of toxicity all the tested fluids can be considered non toxic to aquatic organisms.

\subsection{Tribological properties}

The seizure loads obtained in the extreme pressure tests with the different lubricants tested are showed in Table 5. In these tests the seizure load measured for the fluids is not very high, because high requirements of this property are not needed in the applications for which they have been designed. The values obtained for the biolubricants fulfil the requirements of the reference mineral oil.

Concerning the friction, the vegetable base oils have a natural tendency to lubricate well and this property is reflected in the low levels of friction measured, even lower than the reference mineral fluid (see Table $6)$. However in some cases (HOSO, BIOGIR-01, BIOGIR-02, BIOGIR-03), microweldings have been observed, which mean sudden increases in the friction coefficient (see Figure 3). These microweldings 
Table 4

Biodegradability and Toxicity Test results

\begin{tabular}{|c|c|c|c|c|c|c|}
\hline \multicolumn{3}{|c|}{ BIODEGRADABILITY } & \multicolumn{4}{|c|}{ TOXICITY } \\
\hline \multirow[b]{2}{*}{ Substance } & \multicolumn{2}{|c|}{ OECD $301 F$} & \multicolumn{2}{|c|}{ OECD 201} & \multicolumn{2}{|c|}{ OECD 202} \\
\hline & Biodegradability & $\begin{array}{l}\text { Eco-label } \\
\text { classification }\end{array}$ & $\begin{array}{c}\mathrm{aEC50} \\
(\mathrm{mg} / \mathrm{l})\end{array}$ & $\begin{array}{c}\text { Ecolabel } \\
\text { Classification }\end{array}$ & $\begin{array}{c}\text { aEC50 } \\
(\mathrm{mg} / \mathrm{l})\end{array}$ & $\begin{array}{c}\text { Ecolabel } \\
\text { Classification }\end{array}$ \\
\hline RAGH & $38 \pm 8$ & Non Biodegradable & $>100$ & "Not harmful" & 489 & "Not harmful" \\
\hline BIOGIR-01 & $85 \pm 5$ & Biodegradable & $>100$ & "Not harmful" & $>1000$ & "Not harmful" \\
\hline BIOGIR-02 & $78 \pm 5$ & Biodegradable & $>100$ & "Not harmful" & $>1000$ & "Not harmful" \\
\hline BIOGIR-03 & $73 \pm 1$ & Biodegradable & $>100$ & "Not harmful" & $>1000$ & "Not harmful" \\
\hline BIOGIR-04 & $79 \pm 3$ & Biodegradable & $>100$ & "Not harmful" & $>1000$ & "Not harmful" \\
\hline BIOGIR-05 & $68 \pm 3$ & Biodegradable & $>100$ & "Not harmful" & $>1000$ & "Not harmful" \\
\hline BIOGIR-06 & $89 \pm 7$ & Biodegradable & $>100$ & "Not harmful" & $>1000$ & "Not harmful" \\
\hline
\end{tabular}

${ }^{a}$ EC50: Effective Concentration.

Table 5

Extreme pressure test results

\begin{tabular}{lc}
\hline Lubricant & Seizure load \\
\hline RAGH & 126 \\
HOSO & 160 \\
BIOGIR-01 & 160 \\
BIOGIR-02 & 160 \\
BIOGIR-03 & 160 \\
BIOGIR-04 & 126 \\
BIOGIR-05 & 160 \\
BIOGIR-06 & 160 \\
\hline
\end{tabular}

correspond with a higher wear generation (Figure 4) and have been avoided in some formulations (BIOGIR-04, BIOGIR-05, BIOGIR-06) that contain the adequate additive package to improve this undesirable behavior. These three biolubricants have produced a similar wear to the reference mineral lubricant.

\subsection{Seals compatibility}

As it can be observed in Table 7 the variation of mass, hardness, density and volume suffered by the tested seals (Figure 5) is very low, always lower than $10 \%$, which can be considered a positive result. Only in one case, the test performed with the seal 1-A and the reference fluid, an increase in hardness higher than $10 \%$ has been observed. Nevertheless, as this is the reference fluid it is not identified as a risk, because in the real application

Table 6

Friction and wear test results

\begin{tabular}{lccc}
\hline Lubricant & Mean (COF) & Microweldings & Ball Wear Scar Diameter $(\boldsymbol{\mu m})$ \\
\hline RAGH & 0.11 & No & 526 \\
HOSO & 0.11 & Yes & 822 \\
BIOGIR-01 & 0.10 & Yes & 798 \\
BIOGIR-02 & 0.10 & Yes & 829 \\
BIOGIR-03 & 0.10 & Yes & 901 \\
BIOGIR-04 & 0.09 & No & 530 \\
BIOGIR-05 & 0.10 & No & 517 \\
BIOGIR-06 & 0.10 & No & 521 \\
\hline
\end{tabular}


Table 7

Seal compatibility test results

\begin{tabular}{llcccc}
\hline Seal & Lubricant & $\begin{array}{c}\text { Change in } \\
\text { mass (\%) }\end{array}$ & $\begin{array}{c}\text { Change in Sh } \\
\text { hardness (\%) }\end{array}$ & $\begin{array}{c}\text { Change in } \\
\text { density (\%) }\end{array}$ & $\begin{array}{c}\text { Change in } \\
\text { volumen (\%) }\end{array}$ \\
\hline \multirow{2}{*}{ 1-A } & RAGH & 10.9 & -2.9 & $*$ & $*$ \\
& BIOGIR-06 & 1.7 & -8.6 & $*$ & $*$ \\
$2-A$ & RAGH & 0.0 & -6.3 & 0.0 & 0.2 \\
\multirow{2}{*}{$3-A$} & BIOGIR-06 & -1.3 & 0.0 & 0.7 & -1.8 \\
& RAGH & -2.4 & 1.2 & 1.7 & -3.9 \\
\multirow{2}{*}{$4-A$} & BIOGIR-06 & -1.8 & 0.0 & 0.0 & -1.8 \\
& RAGH & -2.7 & 0.0 & 0.0 & -3.7 \\
& BIOGIR-06 & -1.7 & 0.0 & -0.8 & -1.2 \\
\hline
\end{tabular}
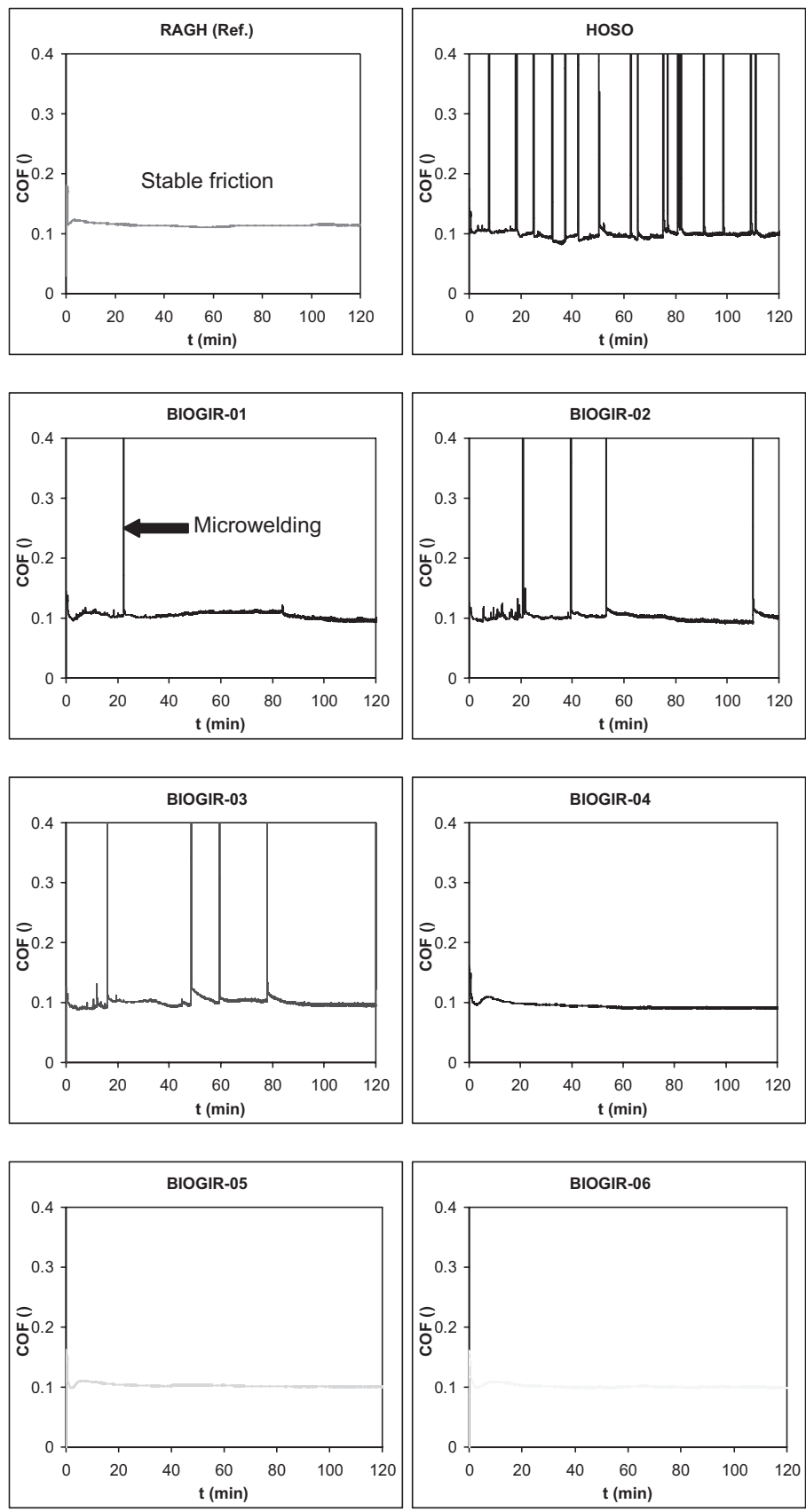

Figure 3. Evolution of friction coefficient (COF) thought time in the friction and wear test 


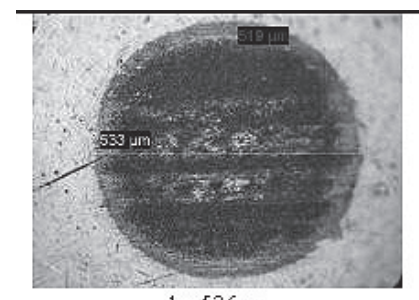

$\mathrm{d}=526 \mu \mathrm{m}$

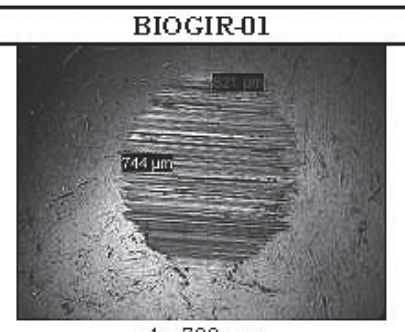

$\mathrm{d}=798 \mu \mathrm{m}$

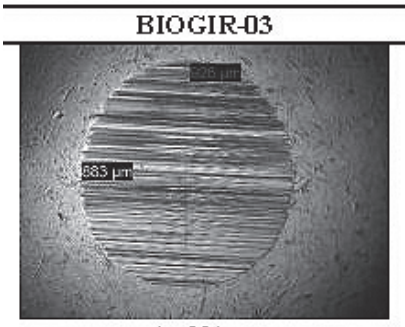

$\mathrm{d}=901 \mu \mathrm{m}$

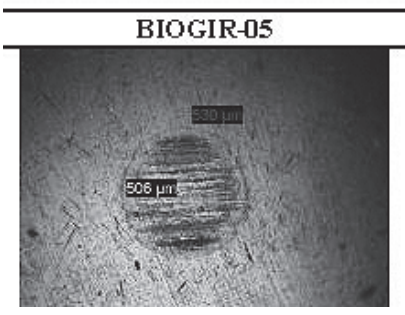

Figure 4. Steel ball wear scars after the friction and wear tests

no failure has been detected due to contact with the reference fluid.

\subsection{Field tests}

The machine selected to perform the field test is an agricultural tractor of AGRIA model 9.100 (see Figure 6 ). The hydraulic system of this tractor has been filled with the selected oil BIOGIR-06 and is working in a field in the South of Spain (Almeria).

The control of the test has been carried out in TEKNIKER. This control has been performed by means of used oil monitoring (water content, oxidation, wear particles, additive control and contamination, control of physical properties) in order to assure that the biolubricant works correctly. The oil has worked without problems during the first 800 hours and still continues successfully.

\section{CONCLUSIONS}

A series of vegetal HOSO lubricants have been developed to be used as hydraulic fluids for agricultural applications.

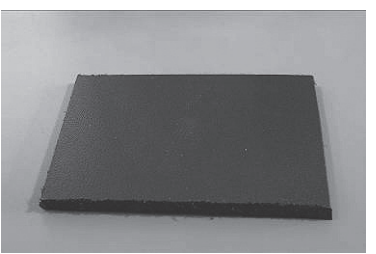

Seal 1-0A

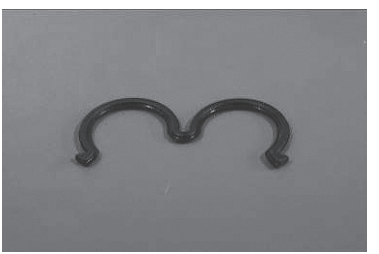

Seal 3-A

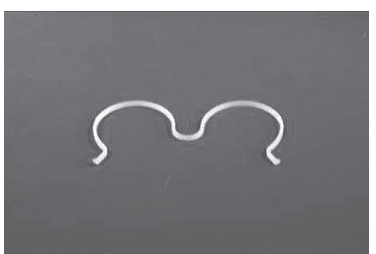

Seal 2-0A

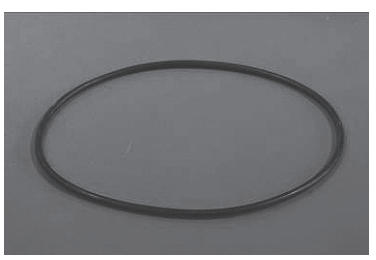

Seal 4-A
Figure 5. Seals used in the hydraulic system of AGRIA agricultural tractor

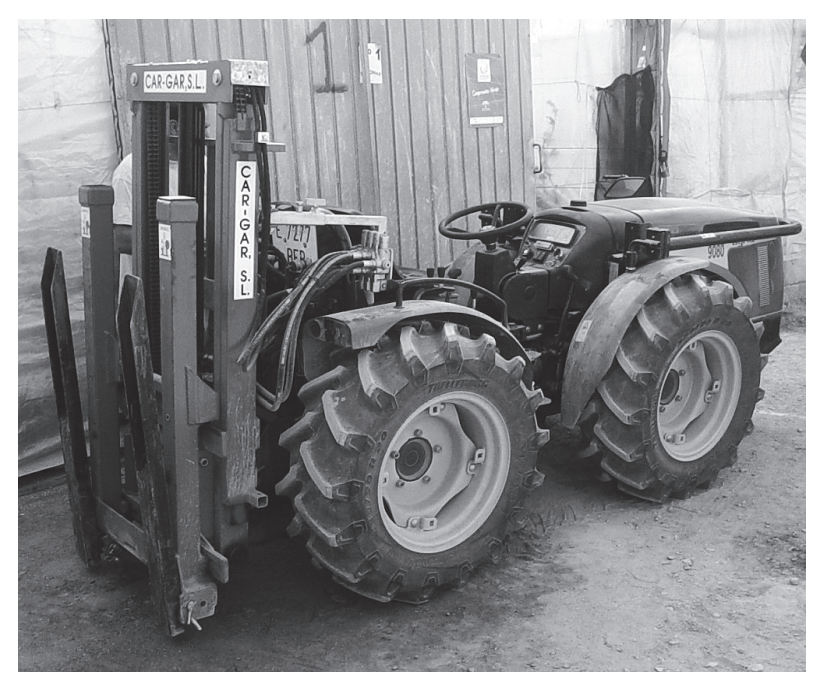

Figure 6. AGRIA tractor used in the field test

The bad performance at low temperatures and the poor resistance to oxidation of the HOSO lubricants have been improved by means of an adequate additivation.

Globally considering the results obtained for all the new formulated biolubricants, the oil BIOGIR-06 has been selected as a prototype to be tested in the field in a real application since it has offered behavior and properties which are equivalent to the reference mineral fluid.

BIOGIR-06 is working in the hydraulic pump of a tractor in a field in the south of Spain (Almería) and its behavior is correct. The lubricant is being analyzed periodically in order to check its stability and performance over time.

\section{ACKNOWLEDGEMENTS}

The authors would like to acknowledge the Spanish Ministry of Science and Technology and Feder Funds for the financing of the project BIOVESIN (PSE420000-2008-04) and the rest of the partners involved 
in this work (Instituto de la Grasa-CSIC, the Complex Fluids Laboratory from the University of Huelva and Thermophysical Properties Laboratory from the University of Santiago de Compostela).

\section{REFERENCES}

Bremmer BJ, Plonsker LM. 2008. BIO-BASED LUBRICANTS a Market Opportunity Study Update. United Soybean Board. http://www.soynewuses.com/ downloads/reports/BioBasedLubricantsMarketStudy.pdf

Fernández Díaz B, Igartua A, Barriga J, Urkiola F, Garcés R, Fernández J, Díaz de Cerio C, Llamazares E, Aguizóniz R. 2008. Vegetable and Biodegradable Lubricants: Formulation, development and testing. LUBMAT Conference, San Sebastián.

Frost \& Sullivan. August 2007. European Biolubricants Markets.

Honary, Lou AT. 2009, Biolubricants: A global overview. International News on Fats, Oils and Related Materials. INFORM, 20, 256-260.

Igartua A., Barriga J. Aranzabe J. 2005. Biodegradable lubricants based on vegetable oils. Report Biodegradable Lubricants. Virtual Tribology Institute Edition, ISBN 8370204-418-X. Spain, II-1- II-2.

Igartua A, Marcaide A, Areitioaurtena O, Aranzabe A, Terradillos J. 2005. European Ecolabel. Report
Biodegradable Lubricants. Virtual Tribology Institute Edition, ISBN 83-70204-418-X, I1-I7.

Petlyuk, Alla M, Adams, Richard J. 2010. Oxidation Stability and Tribological Behavior of Vegetable Oil Hydraulic Fluids. Trib. \& Lub. Tech. 66, 1, 42-48.

Rudnick Leslie R. 2006. Synthetics, Mineral Oils, and Bio Based Lubricants- Chemistry and Technology. Taylor\& Francis Group 353-360; 361-387.

San Lazaro F, Garcés R, Galda P, Fernández J, Arguizónic R, Igartua A, Marcaide A, Areitioaurtena O, Fernández X. 2005, Biodegradable lubricants based on vegetable Oils- II Hydraulic \& Gear Oils. Report Biodegradable Lubricants, Virtual Tribology Institute Edition, ISBN 83-70204-418-X, II1-II5.

Shashidhara YM, Jayaram SR. 2010. Vegetable oils as a potential cutting fluid-an evolution. Trib. Intl. 43, 10731081.

Society of Tribologists and Lubrication engineers. 2010. European Market: an Interview with Dr. Boris Zhmud. Trib. \& Lub. Tech. 66, 1

Van Rensselar J. 2010. Biobased Lubricants: Gearing up for a green world. Trib. Lubr. Tech. 66 1, 32-41.

ISO 15380:2002. "Lubricants, industrial oils and related products (class L) -- Family H (Hydraulic systems) -- Specifications for categories HETG, HEPG, HEES and HEPR".

Recibido: $28 / 5 / 10$ Aceptado: 29/6/10 